\title{
Anna Rytel-Warzocha
}

\section{Partycypacja społeczna w sprawach budżetowych. Model Porto Alegre jako pierwowzór rozwiązań europejskich ${ }^{1}$}

Demokracja partycypacyjna (uczestnicząca), rozumiana jako zespół środków, którymi obywatele mogą wpływać władczo bądź niewładczo na ostateczne rozstrzygnięcia z zakresu władztwa publicznego ${ }^{2}$, znajduje zastosowanie $\mathrm{w}$ różnych dziedzinach życia publicznego zarówno na poziomie ogólnokrajowym, jak i lokalnym. Zauważyć jednak należy, iż zakres partycypacji w mniejszych jednostkach administracyjnych jest zazwyczaj szerszy niż na poziomie ogólnokrajowym, co wynika przede wszystkim z ograniczonego zakresu terytorialnego, jak również z charakteru spraw leżących w kompetencjach władz lokalnych, które w sposób bardziej bezpośredni dotyczą codziennego życia obywateli, wzbudzając tym samym większe społeczne zainteresowanie.

Do spraw, na które na poziomie ogólnokrajowym obywatele nie mają zazwyczaj bezpośredniego wpływu, a już z pewnością nie mogą wypowiadać się w nich w sposób wiążący dla organów państwowych, należą kwestie związane z polityką finansową państwa, w tym przede wszystkim ze sposobem rozdysponowania środków z jego budżetu. Konstytucje niektórych państw, np. Bułgarii ${ }^{3}$ Estonii ${ }^{4}$, Łotwy ${ }^{5}$, Słowacji ${ }^{6}$ czy Węgier ${ }^{7}$, expressis verbis wyłączają możliwość poddania kwestii

1 Artykuł jest zmodyfikowaną wersją referatu wygłoszonego na I Seminarium Młodych Badaczy Prawa Konstytucyjnego, które odbyło się w Mąchocicach Kapitulnych w dniach 11-12 marca $2010 \mathrm{r}$.

2 P. Uziębło, Demokracja partycypacyjna, Gdańsk 2009, s. 18.

3 Konstytucja Republiki Bułgarii uchwalona 12 lipca 1991 r., Dyrżawen Westnik 56/ 13.07.1991, zm. D. W. 85/26.09.2003, D. W. 18/25.02.2005; aktualny tekst w j. angielskim: www.parliament.bg (11.03.2010).

4 Konstytucja Republiki Estońskiej przyjęta w referendum przeprowadzonym 28 czerwca 1992 r., Riigi Teataja z 6 lipca 1992, Nr 26, poz. 349, tłum. A. Puu, [w: ] Konstytucja Estonii, tłum. A. Puu, wstęp L. Garlicki, P. Łossowski, Warszawa 2000.

5 Konstytucja Łotwy z 15 lutego 1922 roku, Valbidas Vestnesis z 1922 r., Nr 141, tłum. L. Gołubiec, [w: ] Konstytucja Republiki Łotewskiej, tłum L. Gołubiec, wstęp P. Kierończyk, Warszawa 2001.

6 Konstytucja Republiki Słowackiej z 1 września 1992 r., tłum. K. Skotnickiego, [w:] Konstytucja Republiki Stowackiej, tłum. i wstęp K. Skotnicki, Warszawa 1993.

7 Konstytucja Republiki Węgierskiej, tłum. H. Donath, wstęp W. Brodziński, Warszawa 2002, 
związanych z budżetem państwa pod referendum ogólnokrajowe. W ostatnim czasie umożliwienie obywatelom bezpośredniego udziału w procedurze budżetowej zyskuje coraz większą popularność na poziomie lokalnym.

Mianem „budżetu partycypacyjnego” (ang. „participatory budgeting”, port. „orçamento participativo”), stanowiącego jedną z form demokracji uczestniczącej na poziomie lokalnym ${ }^{8}$, określa się demokratyczną procedurę, która umożliwia przeciętnym obywatelom uczestniczenie $\mathrm{w}$ dysponowaniu częścią środków publicznych z budżetu danej jednostki administracyjnej ${ }^{9}$. Istotne jest, iż mechanizm ten nie ogranicza się wyłącznie do bezpośredniego wpływu obywateli na to, jak i gdzie środki te powinny zostać zagospodarowane ${ }^{10}$, ale zakłada angażowanie spoleczeństwa na wszystkich etapach procedury budżetowej. Ponadto, aby daną instytucję można było zakwalifikować jako „budżet partycypacyjny”, proces ten musi mieć charakter powtarzalny, nieograniczony do jednorazowych konsultacji czy głosowania powszechnego $\mathrm{w}$ przedmiocie finansów publicznych, zawierać powinien element publicznej debaty dotyczącej wykorzystania wyodrębnionych z budżetu środków finansowych, prowadzonej w trakcie specjalnie w tym celu organizowanych spotkań, jak również swoim zasięgiem terytorialnym wykraczać musi poza granice najbliższego sąsiedztwa, obejmując obszar miasta lub jego części, które stanowią odrębne jednostki administracyjne zarządzane przez organy pochodzące $\mathrm{z}$ wyborów. Istotnym warunkiem jest również stworzenie obywatelom możliwości monitorowania i rozliczania realizacji projektów wyłonionych w ramach budżetu partycypacyjnego ${ }^{11}$.

Cele wprowadzania budżetu partycypacyjnego mają różnorodny charakter - społeczny, administracyjny lub polityczny. W aspekcie społecznym, podstawowym założeniem tej instytucji jest stymulowanie obywateli do udziału w dyskusji

tekst w j. angielskim uwzględniający kolejne nowelizacje: Constitution of the Republic of Hungary, www.legislationline.org (11.03.2010)

8 Wśród innych form demokracji partycypacyjnej na poziomie lokalnym wskazać można referenda lokalne, obywatelską inicjatywę uchwałodawczą oraz referendalną, jak również społeczną partycypację w architekturze masowej, zob. R. Górski, Przewodnik po demokracji uczestniczacej (partycypacyjnej), Poznań-Kraków 2005, s. 34 i n.

9 Por. B. Goldfrank, Lessons from Latin America's Experience with Participatory Budgeting, [w: ] Participatory Budgeting, pod red. A. Shah, Washington. D.C. 2007, s. 92; A. Fölscher, Participatory Budgeting in Central and Eastern Europe, [w:] Participatory Budgeting, op.cit., s. 127.

10 B. Wampler, A guide to Participatory Budgeting, [w:] Participatory Budgeting, op.cit., s. 21.

11 Y. Sintomer, C. Herzberg, A. Röcke, Participatory Budgeting in Europe: Potentials and Challenges, „International Journal of Urban and Regional Research”, Vol. 321, marzec 2008, s. 169. 
publicznej oraz budowa aktywnego i świadomego społeczeństwa obywatelskiego poprzez wspieranie różnego rodzaju ruchów społecznych, jak również stworzenie możliwości partycypacji w życiu publicznym danej jednostki administracyjnej indywidualnym obywatelom. Ponadto, koncepcja budżetu partycypacyjnego opiera się na zasadzie równości oraz idei sprawiedliwości społecznej, czemu służy m.in. przyjęcie indeksu jakości życia jako kryterium przy wyborze projektów do realizacji. Cele administracyjne zakładają natomiast funkcjonowanie administracji publicznej jak najbliżej obywatela. Aktywni obywatele stanowić powinni centralny element dobrej administracji, w której postrzegani są jako uczestnicy, a nie klienci. Cele polityczne oznaczają natomiast dążenie do demokratyzacji procesu administrowania poprzez wprowadzenie elementów demokracji partycypacyjnej. $\mathrm{W}$ ostatnich latach $\mathrm{w}$ wielu państwach, szczególnie w tzw. nowych demokracjach zaobserwować można zmiany w społeczeństwie, które partycypację w sprawowaniu władzy postrzegają jako istotny czynnik życia publicznego. $\mathrm{Z}$ drugiej jednak strony, wdrożenie budżetu partycypacyjnego budzić może obawy po stronie partii politycznych sprawujących rządy, iż instytucja ta spowoduje utratę części władzy oraz osłabienie pozycji, jaką uzyskały one po wyborach ${ }^{12}$.

Wprowadzenie budżetu partycypacyjnego wymaga wspólistnienia trzech podstawowych czynników. Po pierwsze, wprowadzenie tego instrumentu wymaga silnego wsparcia ze strony władz publicznych. Na etapie włączenia obywateli $\mathrm{w}$ proces przygotowywania projektu budżetu instrumenty te muszą przede wszystkim zyskać poparcie organów władzy wykonawczej, które gotowe są zrezygnować z wykonywania części własnych kompetencji, przekazując je obywatelom. Niemniej jednak, ważne jest również sprzyjające stanowisko organów stanowiących danej jednostki organizacyjnej, które nie będą tych procedur blokować. Po drugie, mechanizmy te efektywnie funkcjonować mogą wyłącznie w społeczeństwie obywatelskim, które będzie chciało i będzie miało realną możliwość w nich uczestniczyć. Jak wynika $z$ analizy empirycznej, bezpośrednie formy udziału obywateli w sprawowaniu władzy odnoszą największe sukcesy w społeczeństwach lokalnych, w których widoczna jest działalność stowarzyszeń, organizacji pozarządowych i innych ruchów społecznych. Ostatnim ważnym elementem jest oczywiście posiadanie środków finansowych umożliwiających realizację projektów wybranych przez

12 E.F. Ganuza, Cordoba, [w: ] Participatory Budgets in a European Comparative Approach. Perspectives and Chances of the Cooperative State at the Municipal Level in Germany and Europe, pod red. Y. Sintomer, C. Herzberg, A. Röcke, Volume II (Documents), listopad 2005, maszynopis, s. 514. 
obywateli. Zagwarantowanie obywatelom wpływu na sposób dysponowania środkami publicznymi, poprzez formułowanie sugestii i postulatów, może oczywiście odnosić się do całego budżetu, jakim dysponuje dana jednostka. Niemniej jednak, uprawnienie obywateli w kwestiach budżetowych może być najpełniej realizowane wtedy, gdy w ogólnym budżecie danej jednostki administracyjnej przewidziana zostanie pewna pula środków, których przeznaczenie zależeć będzie wyłącznie od dyskrecjonalnej decyzji obywateli.

Partycypacja obywateli w budżetowaniu nie ma charakteru jednolitego, gdyż jej konkretny kształt zawsze uwarunkowany jest sytuacją społeczną, polityczną i ekonomiczną danej społeczności lokalnej. Różne są też funkcje, które ta forma uczestniczenia obywateli w sprawowaniu władzy spełnia. Przykładowo, doświadczenia niemieckie wskazują, iż stanowi ona sposób na unowocześnienie i usprawnienie procesów decyzyjnych, w Afryce mechanizmy te postrzegane są przede wszystkim jako element dobrej administracji, a w Hiszpanii i Wielkiej Brytanii jako narzędzie urzeczywistniania zasady sprawiedliwości społecznej.

W oparciu o kryterium przedmiotu decyzji podejmowanych przez obywateli wyróżnić można dwa rodzaje budżetu partycypacyjnego. Pierwszy rodzaj koncentruje się na realizacji konkretnych inwestycji, takich jak brukowanie wskazanych przez obywateli dróg, budowa placu zabaw, budowa domu opieki społecznej czy szkoły (public works). Drugi dotyczy natomiast kierunku polityki finansowej organów danej jednostki administracyjnej i polega na wskazywaniu przez mieszkańców ogólnych wytycznych dla tych organów, dotyczących na przykład mieszkalnictwa, transportu publicznego, kultury czy edukacji ${ }^{13}$.

Szukając początków demokracji partycypacyjnej w sprawach budżetowych, należy zauważyć, iż sam pomysł angażowania obywateli w rozstrzyganie kwestii finansowych nie jest ideą nową, gdyż już w pierwszych na świecie referendach zorganizowanych w kantonach szwajcarskich pod koniec XV w., np. w referendum przeprowadzonym w Bern w 1449 r., obywatele średniowiecznych republik rozstrzygali problemy natury finansowej ${ }^{14}$, jak również pod koniec XVII w. mieszkańcy Nowej Anglii mieli możliwość decydowania w kwestiach finansowych na zebraniach miejskich (town meetings). Obecnie, obligatoryjne i fakultatywne referenda w przedmiocie zatwierdzenia budżetu lub jego części występują np. w Szwajcarii

13 B. Wampler, op.cit., s. $34 \mathrm{i} \mathrm{n.}$

14 P. Tsekov, Direct democracy. An Overview of History and Practices, Sofia 2005, s. 13; Funkcjonowanie wczesnych form referendum w kantonach szwajcarskich opisuje W.A.B. Coolidge, The Early History of the Referendum, „The English Historical Review” 1891, Vol. 6, nr 24, s. 675 i n. 
na poziomie kantonalnym i lokalnym, jak też w Stanach Zjednoczonych Ameryki Północnej na poziomie lokalnym ${ }^{15}$.

Partycypacja obywateli w kwestiach budżetowych zyskała jednakże nowy wymiar w 1989 r., kiedy po raz pierwszy innowacyjny mechanizm demokracji uczestniczącej został zastosowany w brazylijskim mieście Porto Alegre. Forma partycypacji społecznej, jaka została tam wdrożona, charakteryzuje się przede wszystkim tym, iż obywatele nie tyle biorą udział w rozstrzyganiu kwestii finansowych poprzez zatwierdzanie propozycji organów władzy, ale bezpośrednio decydują, w jaki sposób środki publiczne mają być rozdysponowane, uczestniczą zatem w projektowaniu budżetu, a następnie poprzez powołane przez siebie komitety czuwają nad jego realizacją ${ }^{16}$. Doświadczenia Porto Alegre uznać można za pierwszy przykład wdrożenia mechanizmu, który powszechnie nazywany jest „budżetem partycypacyjnym”. Zauważyć należy, iż koncepcja budżetu partycypacyjnego w Porto Alegre łączy w sobie elementy demokracji bezpośredniej i reprezentacyjnej. Aby spełniać kryteria legalności, przygotowany z udziałem obywateli projekt budżetu przedstawiany jest burmistrzowi a następnie oficjalnie zatwierdzany przez radę miejską. Decyzje mieszkańców dotyczące budżetu nie mają zatem charakteru prawnie wiążącego dla organów władzy publicznej, aczkolwiek zgodnie z politycznym zwyczajem ostatni etap zatwierdzania budżetu jest wyłącznie formalnością ${ }^{17}$. W ponaddwudziestoletniej historii tej instytucji nie zdarzyło się jeszcze, aby budżet partycypacyjny został odrzucony.

Początki doświadczeń z budżetem partycypacyjnym w Porto Alegre powiązane były z rządami partii lewicowych i głoszonymi hasłami sprawiedliwości społecznej, wyrównywania szans oraz przejrzystości procedur decyzyjnych. Po długim okresie rządów junty wojskowej (lata 1964-1985) wybory wygrała Partia Pracujących (Partido dos Trabalhadores), która w pierwszych latach swoich rządów starała się wprowadzić mechanizmy zapewniające obywatelom bezpośredni udział w procesie decyzyjnym, a tym samym wzmocnić swoją legitymizację w obliczu trudnych decyzji podejmowanych w warunkach nowo odzyskanej demokracji. Partycypacja obywateli w budżetowaniu stanowić miała również sposób na przezwyciężenie trudności finansowych, jak również zwiększenie udziału obywateli zamiesz-

15 Zob. L.P. Feld, J.G. Matsusaka, Budget Referendum and Government Spending: Evidence from Swiss Cantons, May 2002; www.rcf.usc.edu (11.03.2010).

16 G. Baiocchi, Participation, Activism, and Politics: The Porto Alegre Experiment, [w:] Depending Democracy. Institutional Innovations in Empowered Participatory Governance, pod red. A. Fung, E. O. Wright, London 2003, s. 48.

17 R. Górski, Bez państwa. Demokracja uczestnicząca w działaniu, Kraków 2007, s. 70 i n. 
kujących biedniejsze regiony w korzystaniu ze środków publicznych. Mechanizm zapewniający transparentność i jawność procedury budżetowej stanowić miał również narzędzie zwalczania dominującego dotychczas zjawiska klientelizmu, wykluczenia społecznego oraz korupcji. O powodzeniu budżetu partycypacyjnego i pozytywnym odbiorze społecznym świadczyć może widoczny wzrost zainteresowania społeczeństwa udziałem $w$ tej procedurze - w pierwszych dwóch latach w programie pilotażowym udział wzięło około tysiąca mieszkańców Porto Alegre, w 1992 r. liczba ta wzrosła do ośmiu tysięcy, i systematycznie rosła. Obecnie budżetowanie partycypacyjne odbywa się w regularnych rocznych cyklach, angażując około pięćdziesięciu tysięcy mieszkańców miasta, którzy decydują o alokacji środków publicznych stanowiących około $20 \%$ budżetu na dany rok ${ }^{18}$. O przywiązaniu obywateli do tej formy partycypacji w życiu publicznym świadczy również skala protestów przeciwko próbie likwidacji tej instytucji po wyborach wygranych przez koalicję centrolewicową w $2005 \mathrm{r}^{19}$

Brazylijskie miasto Porto Alegre, stolica najbardziej wysuniętego na południe brazylijskiego stanu Rio Grande do Sul, zamieszkałego przez ponad milion trzysta tysięcy osób, podzielone jest na 16 regionów. W regionach tych w marcu każdego roku organizowane są zgromadzenia ogólne mieszkańców, tzw. zebrania przygotowawcze, które przede wszystkim pełnią funkcję edukacyjną i informacyjną, służąc wyjaśnieniu mieszkańcom zasad oraz procedury funkcjonowania budżetu partycypacyjnego oraz zachęceniu ich do aktywnego w niej udziału. Podczas takich spotkań pokazywane są m.in. filmy instruktażowe, objaśniane są podstawowe kwestie dotyczące budżetu miasta, jak również przedstawiane efekty realizacji projektów, które wybrane zostały przez mieszkańców w poprzednich latach.

W kolejnych miesiącach odbywają się mniej formalne spotkania wspólnot sąsiedzkich, jak również ogólne zebrania mieszkańców danego regionu, w których czynnie uczestniczyć mogą mieszkańcy miasta, którzy ukończyli 16 lat. W trakcie spotkań sąsiedzkich uczestnicy dyskutują na temat potrzeb danej wspólnoty oraz inwestycji, które chcieliby zrealizować ze środków publicznych. Efektem tych spotkań, w których udział bierze zazwyczaj kilkadziesiąt osób, jest przygotowanie listy inwestycji o priorytetowym znaczeniu dla mieszkańców danego obszaru. $\mathrm{Na}$ tym etapie, trwającym od kwietnia do czerwca, obywatele biorą również udział w spotkaniach tematycznych poświęconych poszczególnym sektorom życia pu-

18 B. Wampler, op.cit., s. 24; History of Participatory Budgeting, Participatory Budgeting Project, www.participatorybudgeting.org (11.03.2010).

19 Zob. R. Górski, op.cit., s. 97 i n. 
blicznego, takim jak transport, urbanistyka i organizacja miasta, edukacja i kultura, zdrowie i opieka społeczna oraz rozwój gospodarczy i reforma podatkowa, w trakcie których rozważane są inwestycje istotne z punktu widzenia całego miasta, co ma na celu dokonanie hierarchizacji priorytetów sektorowych, jak również podniesienie merytorycznej jakości projektów obywatelskich ${ }^{20}$. Mobilizacja obywateli na tym najniższym poziomie jest zazwyczaj bardzo wysoka, gdyż w trakcie zebrań wyłaniani są delegaci poszczególnych wspólnot sąsiedzkich (neighbourhoods) do regionalnego forum budżetowego, a od poziomu frekwencji w wyborach tych delegatów uzależniona jest ich liczba. Ponieważ ostateczne decyzje w kwestii wyboru projektów do finansowania zapadają na forum delegatów, większa liczba wybranych przedstawicieli zwiększa szansę wyboru projektu realizującego interesy danej wspólnoty ${ }^{21}$. W trakcie ogólnych zebrań regionalnych uczestnicy wybierają natomiast po dwóch reprezentantów do miejskiej Rady Budżetu Partycypacyjnego, której zadaniem jest skoordynowanie żądań przedstawionych przez każde z regionalnych forów delegatów w celu opracowania miejskiego rocznego planu inwestycyjnego $\mathrm{w}$ porozumieniu $\mathrm{z}$ władzami miasta oraz przedstawienia go organowi stanowiącemu w celu zatwierdzenia. Warto podkreślić, iż za organizację posiedzeń wspólnot sąsiedzkich oraz zebrań delegatów, jak również za zapewnienie podstawowego zaplecza technicznego, odpowiedzialne są organy władzy publicznej.

W czerwcu odbywają się regionalne fora budżetowe, których najważniejszym zadaniem jest wyłonienie projektów do sfinansowania w następnym roku budżetowym. Na podstawie przedstawionych przez delegatów list priorytetów, przygotowanych wcześniej przez społeczności sąsiedzkie, opracowywana jest jednolita lista priorytetów dla całego regionu. Dystrybucja środków finansowych na realizację wskazanych przez obywateli projektów oparta jest na dwóch kryteriach. Pierwszym jest indeks jakości życia, który powoduje, iż wspólnoty bogatsze, z lepiej rozwiniętą infrastrukturą, otrzymują mniejszy procent środków niż obszary ubogie, gdzie takiej infrastruktury brakuje. Drugie kryterium decydujące o rozdziale środków publicznych stanowi natomiast poziom aktywności społeczności poszczególnych wspólnot ${ }^{22}$.

20 Por. R. Menegat, Participatory democracy and sustainable development: integrated urban environmental management in Porto Alegre, Brazil, „Environment and Urbanization” 2002, Vol 14, nr 181, s. 187.

21 The Experience of the Participative Budget in Porto Alegre Brazil, Porto Alegre City Hall, www.unesco.org, s. 4. (11.03.2010).

$22 \mathrm{~W}$ sprawie procedury realizacji budżetowania partycypacyjnego w Porto Alegre zob. J. Verhulst, Orçamento participativo: The remarkable experience of direct democracy in a Brazilien 
Analiza empiryczna wskazuje, iż wśród inwestycji najczęściej finansowanych $\mathrm{w}$ początkowych latach funkcjonowania budżetu partycypacyjnego znalazła się budowa sieci kanalizacyjnej (w latach 1989-2000 odsetek mieszkańców posiadających do niej dostęp wzrósł z 46\% do 83\%) oraz budowa brukowanych ulic (w roku 2000 rocznie brukowanych było 30 kilometrów dróg, podczas gdy na początku lat dziewięćdziesiątych jedynie cztery kilometry), dzięki czemu rozległe obszary, wcześniej pokryte błotem, stały się dostępne dla autobusów, śmieciarek, karetek i samochodów policyjnych, co w znaczącym stopniu podniosło bezpieczeństwo i jakość życia w tych dzielnicach. Dzięki nowej formule dysponowania środkami budżetowymi wzrosła również liczba publicznych szkół miejskich, z dwudziestu dziewięciu w roku 1988 do dziewięćdziesięciu dwóch w 2004 r. oraz, w tym samym okresie, liczba społecznych placówek zdrowia wzrosła z trzynastu do stu sześćdziesięciu czterech ${ }^{23}$. Ponadto, wprowadzenie mechanizmów budżetu partycypacyjnego przyczyniło się do rozwoju społeczeństwa obywatelskiego, o czym świadczyć może fakt, iż liczba aktywnie działających wspólnot sąsiedzkich wzrosła z dwustu czterdziestu w 1986 r. do pięciuset czterdziestu w 1998 r. ${ }^{24}$

Pozytywne doświadczenia Porto Alegre z początku lat dziewięćdziesiątych XX w. spowodowały, iż instytucja budżetu partycypacyjnego wprowadzona została $\mathrm{w}$ wielu innych brazylijskich miastach, jak również, miastach pozostałych państw Ameryki Łacińskiej, a następnie znalazła uznanie na pozostałych kontynentach w Ameryce Północnej, Europie, Afryce ${ }^{25}$ i Azji ${ }^{26}$. Obecnie różne formy budżetu partycypacyjnego funkcjonują w ponad tysiąc dwustu społecznościach lokalnych na całym świecie, angażując ponad $25 \mathrm{mln}$ obywateli ${ }^{27}$.

W Europie liczba miast umożliwiających obywatelom bezpośredni udział w budżetowaniu stale rośnie. W 2000 r. pionierskich miast, które wdrożyły budżet partycypacyjny, było zaledwie sześć, w 2005 r. pięćdziesiąt pięć, a w 2008 r. już

town, http://home.scarlet.be/ pin02936/directdemorcamento.html. (11.03.2010); B. Wampler, op.cit., s. 24 i n.

23 R. Górski, op.cit., s. 91.

${ }^{24}$ G. Baiocchi, op.cit., s. 51.

25 Zob. szerzej: A. Shall, Sub-Saharan Africa's Experience with Participatory Budgeting, [w:] Participatory Budgeting, op.cit., s. 191 i n.; A. Fölscher, Participatory Bugdeting in the Middle East and North Africa, [w: ] Participatory Budgeting, op.cit., s. 225 i n.

26 Zob. szerzej: A. Fölscher, Participatory Bugdeting in Asia, [w:] Participatory Budgeting, op.cit., s. 157 i n.

${ }_{27}$ Wykaz udokumentowanych przykładów implementacji budżetu partycypacyjnego przedstawia Y. Cabannes, Participatory budgeting: a significant contribution to participatory democracy, „Environment \& Urbanization” 2004, Vol. 16, nr 1, s. 30. 
ponad sto. Najbardziej znane przypadki zastosowania tych mechanizmów występują w Hiszpanii, Francji, Włoszech, Wielkiej Brytanii i Niemczech, aczkolwiek forma tej instytucji w Europie nie ma charakteru jednolitego ${ }^{28}$. Zauważyć należy, iż najpełniej idea bezpośredniego włączenia obywateli w procedury dysponowania budżetem lokalnym realizowana jest tam, gdzie jako model przyjęto rozwiązania z Porto Alegre. W wielu miastach Hiszpanii, np. w Sewilli oraz Kordobie, zakres partycypacji społecznej jest szeroki, gdyż obywatele mają możliwość decydowania nie tylko w kwestii rozdysponowania środków publicznych, ale również mają wpływ na określenie procedur, w jakich to się odbywa, na kryteria, według których dokonywana ma być ocena zgłaszanych projektów, jak również na ocenę poszczególnych projektów w zgodzie z ustalonymi przez siebie wytycznymi. Ponadto, co do zasady, decyzje podejmowane przez obywateli mają charakter wiążący, podczas gdy np. w Niemczech decyzje obywateli przyjmują charakter rekomendacji adresowanych do właściwych organów samorządowych.

Idea społecznej partycypacji w budżetowaniu znalazła podatny grunt również w państwach Europy Środkowo-Wschodniej, gdzie obecnie, w różnych formach, występuje w takich państwach jak Albania, Armenia, Bułgaria, Mołdawia, Polska, Rumunia, Ukraina czy Rosja ${ }^{29}$. Zauważyć jednak należy, iż w krajach tzw. nowych demokracji, pomimo stworzenia prawnych instrumentów pozwalających obywatelom bezpośrednio uczestniczyć w dysponowaniu środkami publicznymi, partycypacja ta jest dość słaba, czego powodem są zarówno uwarunkowania historyczne powodujące nieufność, brak wiary w realność bezpośredniego decydowania i pasywność obywateli, jak i czynnik ekonomiczny, gdyż środki finansowe w lokalnych budżetach często nie wystarczają nawet na pokrycie najpotrzebniejszych potrzeb społeczności lokalnej ${ }^{30}$.

Jak podkreśla się często $\mathrm{w}$ literaturze, mechanizmy demokracji uczestniczącej, takie jak budżet partycypacyjny, zwiększają zaangażowanie obywateli w sprawy publiczne, edukują, zwiększając ich świadomość publiczną, a z drugiej strony

28 Dostrzegając różnorodność i wielość form budżetu partycypacyjnego występującego w Europie, Y. Sintomer, C. Herzberg, A. Röcke wyróżnili sześć typów idealnych tej instytucji - europejską wersję modelu Porto Alegre, uczestnictwo zorganizowanych grup interesów, fundusz społeczności lokalnej na poziomie dzielnic i miast, negocjacje publiczno-prywatne, partycypację sąsiedzką i konsultacje społeczne finansów publicznych; zob. Y. Sintomer, C. Herzberg, A. Röcke, op.cit., s. 169 i n.

29 Na temat budżetowania partycypacyjnego w państwach Europy Środkowej i Wschodniej zob. A. Fölscher, Participatory Bugdeting in Central..., s. 127 i n.

30 Participatory Budgeting, op.cit., s. 7. 
zwiększają efektywność rządów oraz przejrzystość procesów decyzyjnych, redukując zjawisko demokratycznego deficytu ${ }^{31}$. Ponadto, sukces budżetowania partycypacyjnego związany jest z realizacją zasady sprawiedliwości społecznej. Poprzez stworzenie systemu alokacyjnego środki publiczne inwestowane są w regionach, których społeczności najbardziej tego potrzebują, przy czym to obywatele sami wskazują, jakie inwestycje są dla nich priorytetowe.

\section{Summary}

\section{Participatory budgeting. The model of Porto Alegre as a prototype of European solutions}

Participatory democracy, which provides citizens with the opportunity to influence the decision-making process in a direct way, has become an important element of a public life both on the national and local level. One of the forms of participatory democracy, which is becomming popular on the local level is "participatory budgeting” („orçamento participativo”). In a shortcut, it can be described as a democratic procedure that makes people able to decide on a local budget, engaging them on all levels of a budget procedure - proposals, allocation and control over its execution. The institution is not uniform, as it always depends on the social, political and economic environment in which it has been implemented. For the first time participatory budgeting was successfully introduced in a Brazilian town Porto Alegre in 1989 and since than it has been spread over the world, including many cities in Europe.

31 B. Wampler, op.cit., s. 21. 